\title{
BEYOND WOODHOUSE: DEVISING NEW PRINCIPLES FOR DETERMINING ACC BOUNDARY ISSUES
}

\author{
Ken Oliphant*
}

\begin{abstract}
This paper argues that there is a need to identify new, mid-level principles that provide guidance as to how to draw the boundaries of ACC for as long as it remains a scheme of limited scope. The Woodhouse principles are not suited to this task as they point towards a universal scheme, embracing both injury and illness. The author believes that it is necessary to adopt a principled approach to what is included in ACC and what is left outside. The paper concludes by suggesting that these new principles should be based on a consideration of the nature of the dual public/private responsibility for incapacity and that where the question, "is it legitimate to leave this category of incapacity to the private sphere?" is answered negatively, there is a case for extending the scope of ACC coverage, even if this means transgressing the boundary between injury and illness.
\end{abstract}

\section{INTRODUCTION}

The boundary issues I am concerned with are summarised in the following question: Which injuries or incapacities are best covered by ACC, and which may reasonably be left outside the scheme? I believe that a principled approach to such questions is necessary, but that the relevant principles have not been subjected to sufficient critical examination in recent times. My starting point is that the Woodhouse principles, despite their critical role in the establishment of the scheme and their undoubtedly iconic status, cannot serve as the foundation for today's ACC. They point towards a universal scheme, embracing both injury and illness, not a scheme limited by and large to the former. Accordingly, they can provide little assistance in determining where the boundaries of a limited scheme are best drawn. As a consequence, the dividing line between (compensable) injury and (non-compensable) illness has assumed a significance that it does not warrant, and the consequent "accident focus" has effectively precluded the selective extension of ACC rights into the

* Senior Lecturer, Cardiff Law School. I am extremely grateful to Richard Gaskins and Geoff McLay for their encouragement and patience while I refined the arguments in this paper, and for their lucid and penetrating comments on previous drafts. The article is much better than it would have been without their assistance, even if there is still much within it with which they would strongly disagree. 
area of sickness and disability. I shall argue that recognition of a principle of "private responsibility", alongside the Woodhouse principle of "community responsibility", facilitates an analysis whereby some selective extensions of that nature are justified on a principled basis.

\section{THE WOODHOUSE PRINCIPLES ELABORATED}

Of the five principles that Sir Owen Woodhouse identified as underpinning his recommendations, he described two as "fundamental". ${ }^{1}$ These were "community responsibility" and "comprehensive entitlement". The first referred to an obligation on the state: "[j]ust as a modern society benefits from the productive work of its citizens, so should society accept responsibility for those willing to work but prevented from doing so by physical incapacity." 2 This was an argument of social solidarity, a philosophy that already underpinned the provision of medical and health services in New Zealand. ${ }^{3}$ It was supported by a further argument based on the community's causal responsibility for injuries resulting from activities from which everyone benefited: ${ }^{4}$

Since we all persist in following community activities, which year by year exact a predictable and inevitable price in bodily injury, so we should all share in sustaining those who become the random but statistically necessary victims. The inherent cost of these community purposes should be borne on the basis of equity by the community.

The second principle - comprehensive entitlement - "follow[ed] automatically": "[i]njury, not cause, is the issue." 5 The remaining principles were the provision of real compensation, the promotion of complete rehabilitation, and administrative efficiency. ${ }^{6}$

I am not the first to observe that the two fundamental Woodhouse principles point towards a universal no-fault scheme covering incapacities of all sorts, and not a scheme limited (by and large) to "accidents". The replacement of tort and other existing compensation mechanisms by an integrated accident compensation scheme could be justified as a pragmatic first step, going far enough to justify the abolition of existing sources of compensation but not so far as to demand the input of resources in excess of those required under the previous mixed system. And the adoption of a test of "accident" in place of fault at least covered those cases where the community's causal

1 New Zealand Royal Commission of Inquiry into Compensation for Personal Injury Compensation for Personal Injury in New Zealand: Report of the Royal Commission of Inquiry (Government Printer, Wellington, 1967) paras 4-7 [Woodhouse Report].

2 Woodhouse Report, above n 1, para 56.

Woodhouse Report, above n 1, para 5.

$4 \quad$ Woodhouse Report, above n 1, para 56.

5 Woodhouse Report, above n 1, para 6. "Injury" here seems to be synonymous with "incapacity" rather than indicating any distinction between injury by accident and incapacity resulting from sickness or disease.

6 Woodhouse Report, above n 1, para 4. 
responsibility for incapacity was most obvious. But the logic of the Woodhouse principles goes further. Even the argument of causal responsibility extends beyond the category of accidental injuries and encompasses incapacities resulting from "man-made" diseases and processes. ${ }^{7}$ The logic of social solidarity goes further still. It abandons the focus on the cause of incapacity which is still evident in the argument of causal responsibility (the cause there not being "fault", as under tort, but human activities which predictably result in incapacity) and bases itself instead on the shared interests and reciprocal duties of the individual and the community. The community's obligation to compensate its members is triggered by the mere fact of incapacity, which deprives individuals of "their ability to contribute to the general welfare." ${ }^{8}$ It is clear that it was this argument of social solidarity, not that of causal responsibility, that carried most weight for the Woodhouse Commission. When the principle of community responsibility was first identified in the Woodhouse Report, it was explained purely in terms of social solidarity - with no mention at all of causal responsibility. ${ }^{9}$ And when the Woodhouse Report claimed that its principle of comprehensive entitlement followed automatically, its premise cannot have been the argument of causal responsibility - for the simple reason that it considered injury, not cause, to be the issue. So it was the argument of social solidarity that underpinned the Woodhousian principle of community responsibility, and that argument offers no grounds for limiting compensation rights to cases of accidental injury. Paradoxically, therefore, the fundamental principles on which the Woodhouse Commission rested its recommendation of an accident compensation scheme, once their logic is elaborated, themselves provide the basis for a principled critique of the scheme's limited scope.

\section{PURSUING THE WOODHOUSE LOGIC: EXTENDING COVER TO SICKNESS AND DISEASE}

It appears that Sir Owen Woodhouse himself accepted that the inherent logic of his principles pointed towards a universal scheme, and that he recommended an accident scheme only as a temporary staging post on the road to universality. He expressly contemplated extending the scheme to embrace illness and other incapacity if his no-fault prototype should prove workable, ${ }^{10}$ and indeed proceeded in 1974 to recommend an all-embracing scheme for both injury and illness in his report on Compensation and Rehabilitation in Australia, though his recommendations for Australia were never implemented. ${ }^{11}$ This view of the Woodhouse principles' inherent logic is also supported

7 See, generally, Jane Stapleton Disease and the Compensation Debate (Oxford University Press, Oxford, 1982).

$8 \quad$ Woodhouse Report, above n 1, para 55.

9 Woodhouse Report, above n 1, paras 4-5.

10 Woodhouse Report, above n 1, para 290(b).

11 Australian National Rehabilitation and Compensation Committee of Inquiry Compensation and Rehabilitation in Australia: Report of the National Committee of Inquiry (Australian Government Publishing Service, Canberra, 1974). The Chairman of this Committee was A Owen Woodhouse. See 
by a consideration of subsequent attempts to "complete" the Woodhousian project in New Zealand by extending no-fault compensation rights to cases of sickness and disability, though their failure emphasises the practical difficulties of attaining that goal.

The first official consideration of the extension of ACC to sickness and disability was initiated just a year after the scheme's inauguration. In July 1975, the Labour Government announced the establishment of a working party whose terms of reference were to: ${ }^{12}$

enquire into and report on the desirability, practicability, method and cost of extending the accident

compensation scheme to provide, when appropriate, comparable compensation for persons who suffer

incapacity as a result of sickness, disability, disease, or congenital defect. ...

In December 1975, however, a new National Government came to power and, considering the costs of extension to be too high, it disbanded the Committee in 1977 , before its work was finished. ${ }^{13}$

The next official consideration of the issue was almost 10 years later. In August 1986, an internal report by a committee of government officials noted that no-fault compensation for illness as well as injury was "the logical extension of the five founding principles", 14 to which its terms of reference required it to adhere. It found that the full extension of ACC benefits was not then a feasible option, as the costs would greatly exceed those of ACC and major additional sources of revenue would have to be found, but it believed that the option of introducing a new scheme to cover all serious disability, with a lesser range and/or value of benefits than was then available to injury victims, merited further consideration. ${ }^{15}$ Initial indications were that a socially acceptable scheme of that nature could be developed with a net cost increase of less than 50 per cent, which was equivalent to 1 per cent of payroll. ${ }^{16}$ Whether the scheme should be extended to cover illness, however, was a question for ministers, not officials, and such a decision could only be taken on the basis of detailed costings which were not available at the time. The Committee recommended

further Geoffrey Palmer Compensation for Incapacity: A Study of Law and Social Change in New Zealand and Australia (Oxford University Press, Wellington 1979) 328-330 and Harold Luntz "Looking Back at Accident Compensation: An Australian Perspective" (2003) 34 VUWLR 279.

12 This and other archive material may be found in Archives New Zealand (AACT 620, box 2476). See further Palmer, above n 11,330-332.

13 Palmer, above n 11, 332.

14 New Zealand Officials' Committee Review by Officials' Committee of the Accident Compensation Scheme (vol 1, Government Printer, Wellington, 1986) v.

15 New Zealand Officials' Committee, above n 14, iv.

16 New Zealand Officials' Committee, above n 14, iv and 83. At the time, the average levy rate for employers was 0.77 per cent: New Zealand Officials' Committee, above n 14, 56. 
further investigation and, before any action was taken, the future of the scheme was considered in two independent reports.

In April 1988, the Royal Commission on Social Policy, chaired by Sir Ivor Richardson, endorsed the principles of community responsibility and comprehensive entitlement, ${ }^{17}$ and urged the taking of steps to reduce the stark and inequitable distinction between the sick and the disabled, on the one hand, and the injured, on the other. ${ }^{18}$ The principle of community responsibility required that all "should help share the burden of sickness and disablement in general."19 The principle of comprehensive entitlement could "be seen as arguing for the extension of compensation to cover illness." ${ }^{20}$ The Royal Commission also endorsed a further principle of equality of treatment, which provided further support for such extension by its explicit statement that "those with similar needs should be treated equally."21 It recommended that equality of treatment was to be achieved by extending the accident compensation scheme, as practicable and with modifications, to cover the sick and disabled, ${ }^{22}$ but it considered that it would be too costly to seek full equality of treatment in the short term. The costs of a scheme in which current ACC entitlements were extended to the sick and disabled were - insofar as it was possible to estimate from the admittedly imprecise statistics available - perhaps four times those of the existing scheme. ${ }^{23}$ The Royal Commission accordingly considered that, as an interim step pending more accurate costing of full extension, the extension of benefits under the scheme should take place incrementally and be restricted to the seriously ill and disabled. ${ }^{24}$ It argued that that process should be facilitated by reducing the entitlements available under the scheme, for example, by increasing the "pause period" before weekly compensation was paid from one week to four, by terminating the right to earnings-related compensation after two years, after which time weekly compensation would be paid at a flat rate, and by abolishing lumpsum compensation for non-economic loss and introducing a disability allowance in its place. ${ }^{25}$

17 Royal Commission on Social Policy "Report of the Royal Commission on Social Policy" [1987-90] XII AJHR H2 vol 2, 758 and vol 3, 581.

18 Royal Commission on Social Policy, above n 17, vol 2, 758; vol 3, 608.

19 Royal Commission on Social Policy, above n 17, vol 3, 576-577.

20 Royal Commission on Social Policy, above n 17, vol 3, 578.

21 Royal Commission on Social Policy, above n 17, vol 3, 577.

22 Royal Commission on Social Policy, above n 17, vol 3, 595.

23 Royal Commission on Social Policy, above n 17, vol 3, 596.

24 Royal Commission on Social Policy, above n 17, vol 2, 760-2; vol 3, 596-602.

25 Royal Commission on Social Policy, above n 17, vol 2, 759-60; vol 3, 583-594. 
These reductions also served to promote individual and fiscal responsibility, the latter referring in particular to the taxpayer's willingness to provide continued funding for the scheme. ${ }^{26}$

Later the same year, the Law Commission also urged the extension of the scheme to cover illness "as soon as possible". ${ }^{27}$ In its view, the distinction between the injured and ill was "anomalous" as it gave "hard emphasis to ... the inequality of luck." 28 The distinction was also inconsistent with the principle of community responsibility: "[t]he responsibility of the community to take up some of the costs is the same in the one case as the other." 29 Recognising the uncertain costs of a universal scheme, the Law Commission recommended that the extension should proceed by stages, starting with the provision of health services on an equal basis. Cover could subsequently be extended to those with congenital incapacities already supported by the social welfare system, then to those with serious disabilities, and finally to those with less serious disabilities. ${ }^{30}$ In order to facilitate that process, the Law Commission proposed the immediate abolition of lump-sum awards for bodily pain and loss of bodily function, to be replaced by new periodic payments for permanent disability. It considered the lump sums to be a "barrier" obstructing the scheme's extension to illness: "[a] lump sum for pain and suffering for illness could not be justified." ${ }^{11}$ In the longer term, the Law Commission considered, the costs of extension could be met, if necessary, by reducing weekly compensation from 80 per cent of pre-accident earnings to 75 per cent. ${ }^{32}$ This was preferable to the Royal Commission's approach of limiting the period for which earnings-related compensation was paid, as this would impact most significantly upon the most seriously injured. ${ }^{33}$

Pursuing a more ambitious reform than that proposed by the Law Commission, the Labour Government announced in 1989 that it intended to extend the scheme to sickness at a single stroke. ${ }^{34}$ After "extraordinary efforts" to estimate costs, it determined that the costs of extension could be met by using the money already spent on sickness and invalids benefits, provided there was some "tightening up" of benefits. ${ }^{35}$ The following year, the Government introduced the

26 Royal Commission on Social Policy, above n 17, vol 3, 583.

27 New Zealand Law Commission Personal Injury: Prevention and Recovery (Report on the Accident Compensation Scheme) (NZLC R4, Wellington 1988) para 26(1).

29 New Zealand Law Commission, above n 27, para 56.

30 New Zealand Law Commission, above n 27, para 7.

31 New Zealand Law Commission, above n 27, para 193.

32 New Zealand Law Commission, above n 27, para 66.

33 New Zealand Law Commission, above n 27, para 187.

34 See generally Geoffrey Palmer "New Zealand's Accident Compensation Scheme: 20 Years on" (1994) 44 U Toronto LJ 223, 234-236.

35 Palmer, above n 34, 235. 
Rehabilitation and Incapacity Bill 1990 that would have extended the compensation scheme to all incapacity. ${ }^{36}$ As a quid pro quo, the Bill would at the same time have reduced the rate of weekly compensation to 75 per cent of pre-accident earnings, extended from one week to two the waiting period before weekly compensation was paid, paid only flat-rate compensation for the next four weeks, and replaced the lump sums for non-pecuniary loss with an entitlement to a disability pension. But a general election was approaching and Labour, already performing badly in the polls, was shortly afterwards voted out of office. Writing in 1994, Sir Geoffrey Palmer, who was Prime Minister when the Bill was introduced, attributed its failure to excessive wrangling within government as to its precise terms, which resulted in it being presented to Parliament late in Labour's term of office and in a form which, because of excessive benefit cuts, was unattractive. He conceded that he had been over-ambitious and ought to have implemented the Law Commission's more limited proposals instead. ${ }^{37}$

Since 1990, there has been no official proposal for the extension of no-fault compensation to the sick and the disabled. This, and the history of unimplemented proposals, supports four conclusions. First, there is widespread agreement that (as argued above) the Woodhouse principles of community responsibility and comprehensive entitlement point irrevocably towards a universal scheme covering sickness and disability as well as injury. In considering the nature of the community's responsibility for incapacity, considerations of social solidarity have been primary and little or no reference has been made to the Woodhouse Commission's argument of causal responsibility. Secondly, the cost of extending current entitlements to the sick and disabled as well as the injured has acted as the single most significant obstacle to the creation of a universal scheme. Although research commissioned by the Labour Government in the late 1980s claimed that this could be achieved by the more effective utilisation of existing resources provided there was some tightening up of benefits - effectively the same feat of prestidigitation as performed by the Woodhouse Commission in 1967 - that research has never been published and the burden surely lies on those who assert this to put their detailed calculations and findings to proof in the public domain. Until such time, it seems prudent to assume that extension would involve a new burden on taxpayers. Thirdly, the increased financial costs of an expanded scheme may be partially offset by reducing the range and value of entitlements. Because of the uncertainty surrounding the costs of expansion, it is impossible to know how much this offset might be worth - or indeed whether the scheme's increased costs would require a reduction in entitlements so great as to violate the Woodhouse principle of "real compensation". Last, there is tension between the Woodhouse principles and independent concerns of fiscal responsibility, and consequently an internal tension between the Woodhouse principles of comprehensive entitlement and real compensation, as (assuming the taxpayer's limited willingness to pay for an expanded scheme) the costs of expansion will have to be

36 Rehabilitation and Incapacity Bill 1990, cl 2(2).

37 Palmer, above n 34, 235-236. 
at least partially offset by a reduction in the compensation payable. The continuing commitment to "real compensation", and indeed compensation at current levels, for the duration of the incapacity, is one reason why the goal of comprehensive entitlement has yet to be achieved.

\section{THE WOODHOUSE PRINCIPLES IN A LIMITED SCHEME}

The previous section demonstrated the widespread agreement that the Woodhouse principles point towards a universal compensation scheme, not one limited in scope to accidents. However, the failure of past attempts to extend the scheme to sickness and disability provide no grounds for confidence that this goal will ever be achieved. We are left with a limited scheme in which the Woodhouse principles in fact provide little assistance in addressing boundary issues. It is my contention here that the failure to identify more suitable principles has left the scheme defenceless against two countervailing tendencies - one expansive, the other restrictive.

In the first place, the failure to enunciate principles for determining the boundaries of a limited scheme has encouraged a process of unreflective expansionism by which the category of compensable injury is incrementally extended in ad hoc fashion, without principled consideration of compensation priorities (that is, criteria for selecting new categories of incapacity for inclusion in the scheme). Assessed in terms of the Woodhouse principles, the boundaries of a limited scheme must always be provisional, always susceptible to improvement by any shift which advances the perceived "ultimate goal"38 of universal coverage. However, the Woodhouse principles provide no criteria for determining which possible extensions should be given priority, which categories of currently uncompensated incapacity are most "deserving", and which "improvements" the tax or levy payer would most readily finance. Why, for example, is it now considered a priority to extend cover in the area of medical misadventure, as a current Bill proposes, ${ }^{39}$ by adopting a test of "treatment injury" which goes far beyond what is necessary to address the principal criticism of the existing law, namely, that it still employs fault as a criterion of cover? The consultation document preceding the reform provides no convincing justification for a reform of the scope proposed. ${ }^{40}$

An informal policy of incremental and ad hoc expansion without any limitation of the scope and value of compensation entitlements threatens to undermine the principle of fiscal responsibility. Such concerns are exacerbated when the expansion is accomplished by judicial decision because it is not in the court's power to adjust premium/levy rates and the decision may upset the financial calculations on the basis of which those rates have been set. An example is provided by the expansive judicial interpretation of the Accident Compensation Act 1982's statutory concept of "personal injury by accident" 41 prior to its replacement in 1992, and in particular by two Court of

38 Palmer, above n 11, 317.

39 Injury Prevention, Rehabilitation, and Compensation Amendment Bill (No 3) 2004.

See Part V Overcoming the Accident Focus (Devising New Mid-Level Principles of Entitlement).

41 Accident Compensation Act 1982, s 2(1). 
Appeal decisions of 1991, Accident Compensation Corporation $v E^{42}$ and Accident Compensation Corporation $v$ Mitchell. ${ }^{43}$ In the former, the Court held that a woman's psychiatric breakdown suffered on the fourth day of a confrontational management course fell within the definition of "personal injury by accident". It was not necessary to show that there had been some particular stressful event at the time when the breakdown occurred, and it was a question of fact and degree in every case whether a causative factor acting over a period of time could be said to constitute an accident as opposed to a process. In the other case, Mitchell, the Court ruled that the statutory concept also covered the case of an infant who had been left profoundly and permanently handicapped by an apnoeic attack (that is, an involuntary cessation of breathing) whose cause could not be identified. The cessation of breathing was unexpected and unintended and the resultant injury could therefore be regarded as arising "by accident". It was not necessary to identify an external triggering factor. Although personal injury caused exclusively by disease or infection was specifically excluded from the statutory definition of "personal injury by accident", 44 there was no evidence that the child's condition had been so caused. Enunciating clearly the Court's expansive approach to the injuries covered by the scheme, Richardson $\mathrm{J}$ stated that "a generous unniggardly interpretation of personal injury by accident is in keeping with the policy underlying the Accident Compensation Act of providing comprehensive cover for all those suffering personal injury by accident." 45 It seems clear that these decisions extended the scheme far beyond what it was originally expected to cover and what the term "personal injury by accident" had previously been understood to encompass. They indicate that the courts' "default mode" at that time was one of expansion towards the Woodhouse goal of comprehensive entitlement - which Richardson J no doubt consciously echoed in the dictum just cited - except where this was clearly precluded, for example, by the statutory exclusion of disease and infection and by the long-established distinction in the case law between "accident" and "process".

Since 1992, the scope for expansive judicial interpretation of covered personal injury has been limited by the more detailed statutory formula introduced by the Accident Rehabilitation and Compensation Insurance Act 1992. But some scope remains, and the Court of Appeal recently cited Richardson J's dictum with approval in deciding that the loss of an unborn child constituted a personal injury to the mother, entitling her to compensation under the scheme. ${ }^{46}$

42 Accident Compensation Corporation v E [1992] 2 NZLR 426 (CA).

43 Accident Compensation Corporation v Mitchell [1992] 2 NZLR 436 (CA).

44 Accident Compensation Act 1982, s 2(1)(b)(ii).

45 Accident Compensation Corporation v Mitchell [1992] 2 NZLR 436, 438-439 (CA) Richardson J.

46 Harrild v Director of Proceedings [2003] 3 NZLR 289, para 19 Elias CJ; para 38 Keith J; paras 80 and 139 McGrath J. 
The second, countervailing movement was in large measure a reaction against the first. It took the form of an unprincipled attempt to reinstate the scheme's originally-intended boundaries, and was pursued in an effort to constrain rising ACC costs by the National Government elected in 1990. A policy document of the following year, Accident Compensation: A Fairer Scheme, announced that "the boundaries of the scheme have been extended over the years to cover situations which most people would have difficulty in reconciling with the common view of what an accident is. This, in turn, has led to cost increases." 47 It proposed replacing the umbrella concept of "personal injury by accident" with a number of precisely defined types of covered personal injury, and this was the approach adopted in the subsequent legislation. ${ }^{48}$ Quite deliberately, the facts of both Accident Compensation Corporation $v E$ and Accident Compensation Corporation $v$ Mitchell were left outside the scheme's revised boundaries. One consequence was a return to the right to sue in the area of psychiatric injury, ${ }^{49}$ which was entirely excluded from the scheme except in cases where it was the result of sexual abuse. ${ }^{50}$ This result was superficially at odds with the emphatic statement in $A$ Fairer Scheme that "there will be no return to the right to sue." ${ }^{51}$ But the small print revealed the get-out clause: "The government has decided that, where there is cover under the scheme, there will be no return to the right to sue for compensation under common law."152 In fact, the Government expressly contemplated that "[a]s the boundaries of cover under the scheme are more clearly defined, it may be possible that (in cases not covered by the scheme) there will be more court actions for damages than in the past." 53

The Government's motivation was in part its concern to constrain costs, and in part its desire to play to its core constituency by reducing the scheme's burden on businesses. Its approach was pragmatic, not principled. Although Government ministers declared that the Woodhouse principles remained valid, ${ }^{54}$ they are only imperfectly restated in A Fairer Scheme, and there is nothing to suggest that they played any role at all in its formulation of the policies announced in that document.

47 William F Birch Accident Compensation: A Fairer Scheme (Office of the Minister of Labour, Wellington, 1991) 31. This was published in July 1991, before the Court of Appeal's decisions in Accident Compensation Corporation v E, above $\mathrm{n}$ 40, and Accident Compensation Corporation v Mitchell, above $\mathrm{n}$ 41, but after the High Court's decisions in favour of cover in the two cases: Accident Compensation Corporation v E [1991] 2 NZLR 228 (HC) and Accident Compensation Corporation v Mitchell [1991] 2 NZLR 743 (HC).

48 Accident Rehabilitation and Compensation Insurance Act 1992, s 8(2).

49 See, for example, Queenstown Lakes District Council v Palmer [1999] 1 NZLR 549 (CA).

50 Accident Rehabilitation and Compensation Insurance Act 1992, s 8(3) and 1st sch.

51 Birch, above n 47, 18 (original capitals omitted).

52 Birch, above n 47, (emphasis added).

53 Birch, above n 47, 17.

54 See Palmer, above n 34, 226. 
Thus, we read that "[t]he principles of no fault and no right to sue, comprehensive coverage of all injury, and cost-effective rehabilitation remain unaffected."55 No mention here of community responsibility! What is more, as I have already noted, the promise not to bring back the right to sue was to be read in a circumscribed sense, for A Fairer Scheme consciously restored the right to sue in some cases, notably cases of negligently-inflicted psychiatric injury. In fact, more decisive than the Woodhouse principles in the formulation of the proposed reforms were what were called the principles of economy and fairness. ${ }^{56}$ However, economy ought only to operate as a consideration limiting the pursuit of independent goals and cannot be regarded as having intrinsic value (even if dressed up as a "principle" of fiscal responsibility), while fairness was given a massively skewed interpretation. In truth, the Government's only concern was with "fairness" to employers, from whom it wanted to remove the burden of funding earners' non-work injuries, which were from then on to be funded by a new premium levied on earners themselves. "Equity" also demanded the experience rating of employers' premiums. ${ }^{57}$ But neither fairness nor equity prompted the Government to do anything about the exclusion from the scheme of the sick and the disabled, even though its election policy had promised that "[t]he State and the individual would share responsibility for funding health care and income maintenance in cases of sickness...". 58 The Ministerial Foreword to A Fairer Scheme did indeed note the "preferred treatment of victims of accidents, compared to victims of sickness, as a consequence of the coverage and assistance provided by the scheme", but the report and the subsequent legislation did nothing to improve the situation of the latter; instead, the Government's strategy in addressing the disparity of treatment was to reduce the benefits available under the scheme to those injured by accident, for example, by introducing new user charges for publicly-funded health services. ${ }^{59}$

My point here is not that explicit reliance upon the Woodhouse principles would have prevented a misguided reform which departed from the Woodhousian vision of an integrated approach to accident compensation by reintroducing the right to sue, albeit in a limited category of cases. Rather it is that the present scheme so manifestly fails to give effect to the Woodhouse principles, because of the exclusion of sickness and disability, that it becomes easy to view those principles as irrelevant: at best, they are paid lip-service and their content devalued; at worst, they are ignored, and cost considerations are given decisive importance (rather than merely acting as practical constraints on the pursuit of principled goals). The failure to develop principles for the

55 Birch, above n 47, 15.

56 Birch, above n 47, iii and 37-38.

57 Birch, above n 47, 23.

58 Birch, above n 47, 23, iv and 14 .

59 Birch, above n 47, n 54, 55. The decision to abolish the lump sums for pain and suffering and loss of enjoyment of life might also be seen in the same light, though the unequal treatment of the injured and the sick was not explicitly identified as a material consideration: see Birch, above n 47, 50-52. 
compensation scheme that actually exists, not the one that many would like to see exist, left ACC rudderless in the stormy waters of party politics.

\section{OVERCOMING THE ACCIDENT FOCUS (DEVISING NEW MID-LEVEL PRINCIPLES OF ENTITLEMENT)}

Because there has been so little analysis of the principles according to which the boundaries of a limited compensation scheme should be drawn, the blunt distinction between "injury" and "illness" has been invested with a significance that it does not deserve by those seeking to steer a middle way between "completion" and cost-driven retrenchment. There is of course a historical explanation for the scheme's focus on accidents. ACC was introduced in place of pre-existing compensation mechanisms - tort, workers' compensation and criminal injuries compensation - which themselves tended to focus on accidental injuries, and was intended to preserve existing compensation rights at least in kind. In seeking a criterion of entitlement to replace "fault", it was understandable that first Woodhouse, then the legislator, should embrace the term "personal injury by accident" which was well-known to them from the workers' compensation legislation. The test of accident was apparently simple to apply, and certainly did not entail the costs of a time-consuming inquiry into fault. Additionally, by excluding incapacity from sickness, disease and congenital incapacity, it proved to be possible to provide "real compensation" without imposing a large new financial burden on the public: most of the cost could be borne simply by redeploying existing sources of funds (primarily, compulsory liability insurance premiums previously paid by employers and motor-vehicle owners). No doubt the creation of a compensation scheme limited to accidents was a prudent first step. But we may question whether policy-makers and law-reformers now should perpetuate that initial focus on accidents. There are certainly clear signs that the scheme has moved on. To give just one obvious example, the scheme no longer channels all claims via the unitary concept of "personal injury by accident", but instead treats "personal injury caused by an accident" as just one type of compensatable injury. ${ }^{60}$ Injuries resulting from (amongst other things) occupational disease or medical misadventure are no longer forced into the category of "personal injury by accident" but instead are covered by the scheme independently. ${ }^{61}$

However, there are signs that an accident focus remains not just in the scheme itself but also in the minds of policy-makers and law-reformers. The October 2004 proposals to reform the law on medical misadventure provide an example. The Injury Prevention, Rehabilitation, and Compensation Amendment Bill (No 3) 2004, if enacted, will replace the concept of "medical misadventure" with a new concept of "treatment injury". ${ }^{62}$ The explicit intention is to introduce

60 Injury Prevention, Rehabilitation, and Compensation Act 2001, s 20(2).

61 Injury Prevention, Rehabilitation, and Compensation Act 2001 s 20(2)(b) (medical misadventure) and (e) (work-related disease).

62 Injury Prevention, Rehabilitation, and Compensation Amendment Bill No 3) 2004, cl 7, amending Injury Prevention, Rehabilitation, and Compensation Act 2001, s 20(2). 
what is effectively a test of "accident" and to "more closely align" the medical injury provisions with the scheme as a whole. ${ }^{63}$ Of course, there are other claimed benefits: the new test will be "fairer" for claimants; it removes fault as the (or a) basis for cover; it reduces the focuses on the actions of the individual healthcare professional; and it will lead to quicker decisions about whether to pay out on claims or not. ${ }^{64}$ However, the consultation document nowhere sets out the principles that warrant the conclusion that the new regime would in fact be "fairer"; indeed there is no explicit reference to the Woodhouse principles, or any other principles, at all. We are left to surmise that the new test would be fairer for claimants because the old test - particularly the criterion of "mishap" unfairly denied cover in respect of serious treatment injuries that did not satisfy the criterion of rarity. ${ }^{65}$ But there is no discussion as to why the new boundaries will be any fairer to those left outside, or why the public should accept an increased tax and premium burden - estimated at \$4.418.7 million as against predicted current-year medical misadventure costs of $\$ 47$ million $^{66}$ - to finance this particular expansion of ACC. What is more, there is a real concern that the perceived desirability of providing cover in respect of "accidents" may have blinded the reformers to consequences that are contrary to principle. As the consultation paper admits, the new legislation will offer no cover in respect of some cases of clinical negligence, namely, those which lead to minor (more accurately, "endurable") injury. ${ }^{67}$ The result is a partial revival of the right to sue. Remarkably, there is no recognition in the consultation document that this could be a drawback: it does not, for example, appear in the list of disadvantages associated with the proposal. ${ }^{68}$ This partial return to fault is doubly undesirable because it not only undermines the no-fault principle but also results in a distortion of priorities, with full tort damages paid to some with relatively minor injuries, and relatively limited ACC benefits paid in more serious cases.

What I believe is needed now is an attempt to identify some new, mid-level principles of entitlement for resolving boundary issues in a limited compensation scheme. I have sought to demonstrate that the Woodhouse principles cannot fulfil that role as their inherent logic points towards "completion", a goal that may never be achieved, and that the lack of mid-level principles of entitlement has resulted in a falling-back upon the blunt distinction between injury and illness by those seeking to steer a middle way between completion and cost-driven retrenchment. Even if

63 Accident Compensation Corporation Review of ACC Medical Misadventure: Consultation Document (Accident Compensation Corporation, Wellington, 2003) 20. The document's focus on accidents is particularly hard to understand given the Minister for ACC's recognition in her Foreword that "accidents in healthcare are different to accidents that happen elsewhere".

64 Accident Compensation Corporation, above $\mathrm{n}$ 63, 20 and 23.

65 Compare, Accident Compensation Corporation, above n 63, 11.

66 Accident Compensation Corporation, above n 63, 22.

67 Accident Compensation Corporation, above n 63, 20.

68 Accident Compensation Corporation, above $\mathrm{n} 63$. 
completion is maintained as a long-term goal, there is still a need for principles for the short-tomedium term and to establish priorities for progression towards the long-term goal.

Specifying what those mid-level principles are, however, is a different matter - and one that I cannot now begin to address in anything other than a very impressionistic manner, with the hope of stimulating further debate by others more qualified than myself. Some of the "new" principles may well prove not to be new at all, but integral to the original Woodhousian vision - although not actually included amongst the five founding principles. Amongst these might be an integrated approach to compensation for personal injuries on a no-fault basis, with the tort remedy wholly excluded. Recognising this as a fundamental guiding principle would immediately call into question the current availability of tort damages in respect of (for example) mental injuries not resulting from physical injuries or from a scheduled sexual offence. ${ }^{69}$ Another principle which clearly influenced the Woodhouse Commission, and is no less weighty now, is giving priority to the most serious incapacities. To Woodhouse, this was relevant primarily in determining the compensation entitlements of those covered by the scheme, but there is no reason why it should not also be relevant in determining the scheme's boundaries. As we have seen, ${ }^{70}$ both the Royal Commission on Social Policy ${ }^{71}$ and the Law Commission in its Report on $\mathrm{ACC}^{72}$ recommended the extension of ACC boundaries to cases of serious illness and disability, in both cases as a step on the road towards a universal scheme (and in both cases requiring a tightening up of available benefits). Something else in the Woodhouse Report that may assist in setting the boundaries of a limited scheme is the argument for community causal responsibility. It could, for example, provide some support for the approach taken in the current medical misadventure reforms: the adverse consequences of treatment ("treatment injuries") ought to be distinguished from adverse outcomes attributable to the underlying condition simply because the former can be causally attributed to the practice of medicine, from which the community as a whole benefits on balance. And it might also support the extension of ACC boundaries to man-made diseases, processes, and so forth, which are not work-related (for example, cumulative environmental exposure to toxic substances). Another principle with which I do think it would be possible to argue is fiscal responsibility, though care must be taken to ensure that this acts only as a second-order principle, constraining the pursuit of goals dictated by the other, first-order principles, and not as a first-order principle in its own right.

One suggestion that I intend to discuss in more detail, because I think it will be more controversial, is that a principle of private or individual responsibility should be recognised

69 Injury Prevention, Rehabilitation, and Compensation Act 2001, s. 26(1)(c) and (d), the latter read with s 21 and Schedule 3.

71 Royal Commission on Social Policy, above n 17, vol 2, 760-2; vol. 3, 596-602.

72 New Zealand Law Commission, above n 27, para 26. 
alongside Woodhouse's principle of community responsibility, and that - pending completion of the original Woodhouse vision - the boundaries of what must be, by definition, a limited compensation scheme should be set by reference to a principle of dual public and private responsibility for incapacity.

\section{DUAL PUBLIC AND PRIVATE RESPONSIBILITY FOR INCAPACITY}

It is scarcely possible to employ the phrase "public/private" in some quarters without drawing howls of derision. In the United Kingdom, and no doubt elsewhere, the idea of public/private partnership brings to mind a number of very controversial political initiatives. But the inevitability of mixing State provision and private initiative is well-recognised in the social policy literature, and not merely amongst those who want to limit the role played by the welfare state. Gøsta EspingAndersen, for example, states that a basic issue that welfare states must address is "deciding on the division of responsibilities between markets, families and governments", ${ }^{73}$ and stresses "the need to rethink policy boundaries and, in particular, the public-private welfare divide."74 And, as we have already touched on to some extent, the balancing of public and private spheres of responsibility has already been addressed in official reports on the future of no-fault compensation in New Zealand. Indeed, there was implicit consideration of this issue even in the Woodhouse Report itself.

The Woodhouse Commission does not use the term private or individual responsibility, but its thinking was clearly shaped by an acceptance that some of the consequences of accidents could reasonably be left to the private sphere - and indeed ought in some respects to be left to that sphere. "The compensation purpose of the scheme," the Woodhouse Report stated, "is ... to shift a fair share of the burden suddenly falling upon individuals as a result of personal injury." ${ }^{75}$ With this in mind, it advocated a concentration of resources on cases of serious injury - even if this meant restricting the benefits recoverable by those suffering minor injuries who would have been entitled to full compensation under the tort system: "[b]y the avoidance of easy help for the minor problem the major effort can be made where it is really needed ...". ${ }^{76}$ The victim of incapacity, the Commission considered, was "for short periods ... able to carry some strain himself."77 It therefore recommended that in cases of short-term incapacity (up to eight weeks) the amount of weekly compensation should be capped at $\$ 25$ per week for the first four weeks (compared with the normal maximum of $\$ 120$ per week). ${ }^{78}$ Furthermore, the Commission considered that "[i]ncentive must be

73 Gøsta Esping-Andersen Why We Need a New Welfare State (Oxford University Press, Oxford, 2002) 11.

74 Esping-Andersen, above n 73, 25.

75 Woodhouse Report, above n 1, para 279(a) (emphasis added).

76 Woodhouse Report, above n 1, para 8.

77 Woodhouse Report, above n 1, para 301.

78 Woodhouse Report, above n 1, 300-301. This proposal was not carried through into the Accident Compensation Act 1972 or the Accident Compensation Act 1974. 
the driving purpose of any effective scheme", and advocated a policy of providing an "incentive to return to work by leaving to each man a fair margin for independent effort."79 ${ }^{79}$ policy is most evident in the recommendation that there should be no complete indemnity for lost earnings and that weekly compensation should be paid at a rate of 80 per cent of pre-accident earnings. Here, the Report explicitly acknowledged "the need to leave some margin of effort to personal initiative." 80

In its 1988 Report, the Law Commission chose to emphasise the importance of "individual responsibility" more explicitly, as a principle to be taken into account alongside those in the Woodhouse Report itself. This new principle denoted ${ }^{81}$

... the responsibility of individuals to take care in respect of actions that might injure themselves or others, their responsibility if injured to bear an appropriate share of the cost, and their responsibility as providers of health care under the scheme - in all cases a responsibility not to abuse the system and not to make unjustified claims on it.

The Law Commission considered that individual responsibility was already reflected in a number of ways in ACC, mentioning amongst other things the waiting period before weekly compensation is paid and the less than full replacement of lost income. ${ }^{82}$ In its recommendations, it sought to enhance individual responsibility - on the part of employers as well as those at risk of injury or actually injured - by increasing the length of the waiting period from one week to two. It explained that this: ${ }^{83}$

... would give a greater incentive to safety for both; both would have an incentive to deal quickly and efficiently with the consequences of an injury once it has occurred; and it could be an immediate form of experience rating for the employer.

The Law Commission considered that the reform would also, by removing a large number of minor injuries from the scheme, enable the system to concentrate on major disabilities. ${ }^{84}$ In the case of minor set-backs, "most people wish to do what they can for themselves."

Shortly before the Law Commission reported, the Royal Commission on Social Policy had developed a more substantial analysis of the appropriate balance to be struck between public and

79 Woodhouse Report, above n 1, para 8.

80 Woodhouse Report, above n 1, para 292.

81 New Zealand Law Commission, above n 27, para 162. See also New Zealand Law Commission, above $n$ 27 , para 181

82 New Zealand Law Commission, above n 27, para 162 and 181.

83 New Zealand Law Commission, above n 27, para 184.

84 New Zealand Law Commission, above n 27, paras 162 and 181.

85 New Zealand Law Commission, above n 27, para 9. 
private responsibility in income-maintenance programmes. It began its statement of its own guiding principles with a renewed commitment to community responsibility, but immediately added the rider that "[c]ommunity responsibility should not unduly undermine individual responsibility." ${ }^{16} \mathrm{It}$ therefore identified "individual responsibility" as the second of its guiding principles, explaining that: "[a]s far as is possible, income maintenance and taxation should not seriously impede the incentives for individuals to achieve financial independence from their own efforts." 87 The Commission then proceeded to identify seven further guiding principles: dignity, equality of treatment, progressivity, cultural diversity, fiscal responsibility, flexibility, and transparency. It considered that the five Woodhouse principles were, taken individually, consistent with its own objectives and principles, ${ }^{88}$ but recommended that its own principles of individual and fiscal responsibility should also be taken into account in deciding the accident compensation scheme's future $^{89}$ There was a need for "a new balancing ... of the crucial principles of individual responsibility, community responsibility and fiscal responsibility." 90 "Individuals and businesses", the Commission argued, "should be prepared to bear themselves a larger share of the cost of lesser injuries, in return for the greater security provided against loss from serious disablement."191 As explained above, that greater security was to be derived from the extension of no-fault benefits to those suffering from serious illness or disability.

This short survey demonstrates that the notion of private responsibility has already received considerable attention in policy debates about the no-fault system, even from those favouring the extension of ACC benefits to the sick and disabled. (It needs scarcely be added that the virtues of private responsibility have been trumpeted by those seeking to trim back the boundaries of the scheme. ${ }^{92}$ ) The debate so far has emphasised two particular ways in which private responsibility may be given effect within a no-fault scheme. First, individuals may be expected to bear most of the cost of minor, short-term incapacities themselves, allowing the community's efforts to be concentrated upon more serious cases. This policy is evident, for example, in the pause period before weekly compensation is payable. Secondly, the amount of compensation paid should leave individuals an incentive to exercise their own initiative during the period of their rehabilitation and encourage a swift return to work (hence, for example, the fractional replacement of lost earnings).

86 Royal Commission on Social Policy, above n 17, vol 2, 734; vol 3, pt 2, 424.

87 Royal Commission on Social Policy, above n 17, vol 2, 734-735; vol 3, pt 2, 424.

88 Royal Commission on Social Policy, above n 17, vol 2, 758; vol 3, pt 2, 576-580.

89 Royal Commission on Social Policy, above n 17, vol 3, pt 2, 583.

90 Royal Commission on Social Policy, above n 17, vol 2, 758.

91 Royal Commission on Social Policy, above n 17, vol 233, 758; vol 3, pt 2, 581 ..

92 See, for example, Birch, above n 47, 8 (contending that the scheme encourages a "move away from individual responsibility"). 
I want to suggest that the balance of community and private responsibility can be considered from another perspective - as an aid to establishing the proper boundaries of "no fault", not just in determining the compensation entitlements of those who have cover. My argument starts from the superficially trite observation that, where community responsibility ends, private responsibility must take over. ACC's current boundaries identify injuries as a matter of community responsibility, and leave sickness and disability - at least so far as income maintenance is concerned - primarily in the sphere of private responsibility. The observation is not merely trite, however, because it challenges us to justify the disparity of treatment that it reveals and to come up with reasoned arguments for leaving what falls outside ACC to the private sphere. My contention here is that, even if we accept a limited no-fault compensation scheme, its boundaries should at least be set with regard to the adequacy of private support mechanisms for those excluded from its scope. I talk here of "private" rather than "individual" support and responsibility because I want to emphasise the role played by others, including family, friends, communities and voluntary associations, in looking after those who suffer misfortune. ${ }^{93}$ And I am not concerned exclusively with ex post facto responses. Advance provision is also crucially important, whether in the form of first-party insurance, or sickness and disability benefits offered as part of an employment package. Of particular note is the ready availability in New Zealand of income protection insurance. A typical policy ${ }^{94}$ replaces an agreed percentage of lost income (up to 75 per cent) or pays an agreed monthly sum in the event of an incapacitating illness - and acts as a top-up to ACC compensation where the statutory maximum limits the amount paid. The insured elects whether to purchase cover for a fixed period following the incapacity (say, two or five years) or till a fixed aged (normally 65). Can it be argued that, because by purchasing such insurance or by negotiating equivalent benefits from their employer individuals have the means to protect themselves in the event of incapacity, sickness and disability can legitimately be regarded as matters of individual responsibility, with state intervention limited to the maintenance of basic subsistence needs? ${ }^{95}$

I do not want to argue strongly for an affirmative answer to that question, but I consider that a plausible answer can be advanced based on the social contract whereby New Zealanders, in return for giving up rights in tort and under workers' compensation, were granted new rights against ACC. ${ }^{96}$ It may be argued that this was essentially an agreement to redeploy existing resources so as

93 See also Royal Commission on Social Policy, above n 17, vol 3, pt 2, 424.

94 See for example, $<$ http://www.tower.co.nz $>$ (last accessed 18 August 2004).

95 It is not an objection that such insurance is currently taken out rather infrequently as the argument, if accepted, could be seen as requiring the government to take positive steps to promote the take-up of income-maintenance policies.

96 The social contract was given explicit statutory recognition in the Injury Prevention, Rehabilitation, and Compensation Act 2001, s 3, but reference to it in policy debates dates back to the period before the scheme's inauguration in 1974. 
to redraw the line between those entitled to compensation in the event of incapacity and those who were not. By getting rid of the costly inquiry into fault, there would be more money in the compensation "pot" and the class of beneficiaries could be extended. But existing rights were to be preserved, at least in kind, and the new scheme was therefore to offer "real" if not "full" compensation - in contrast with the subsistence support offered by social security. It was on that basis that ACC appealed successfully to the self-interest of New Zealanders. It offered an improvement upon the mixed system of compensation that preceded it but, in order to retain the principle of real compensation whilst keeping the costs of the new scheme broadly comparable with those of the old, it was necessary to accept limitations on its scope. Although the resulting boundary lines could be seen as arbitrary, it is plausible to suggest that New Zealanders preferred real compensation to comprehensive entitlement that could only be achieved by reducing benefits to levels that made the scheme hard to distinguish from social security. Rather than extending community responsibility, they opted to take responsibility themselves for misfortunes that fell outside the scope of ACC.

What this reasoning does not justify, however, is the exclusion from ACC - that is, the sphere of community responsibility - of incapacities against which individuals cannot realistically be expected to protect themselves. In such circumstances, the social contract leaves room for the State to step in, even if this requires a radical redefinition of the boundaries of "no fault" and the selective extension of compensation entitlements into the area of sickness and disability where a predominant reliance upon private as opposed to community responsibility is likely to cause undue hardship. One such incapacity is congenital disability.

\section{THE EXTENSION OF ACC BENEFITS TO CASES OF CONGENITAL DISABILITY}

Congenital disability has not really been thought of in New Zealand as a problem for ACC. Under the present law in New Zealand, if a congenital disability results from an accident, or from medical misadventure/treatment injury, or otherwise has cover under the Act, then full ACC benefits are available. In its Report of 1988, the Law Commission did express the hope that ACC entitlements might be extended to those with such disabilities by "deeming" them to be injuries, as a step towards the equal treatment of the injured and the sick. ${ }^{97}$ But it made no proposal to that effect, and did not explore the significant consequences the reform would have for other areas of policy and administration nor did it estimate its cost. ${ }^{98}$ Nor did it explain why this category of case should be given priority over other cases of sickness or disability.

This neglect stands in stark contrast with the interest shown in congenital disability by advocates of "no fault" in other common law jurisdictions. In the United Kingdom, the case of congenital

97 New Zealand Law Commission, above n 27, para 26(4).

98 New Zealand Law Commission, above n 27, para 172. 
disability has been repeatedly highlighted by tort reformers. The Pearson Royal Commission, reporting in 1978, recommended a new no-fault scheme for "severely handicapped" children, one of only two new no-fault schemes in its recommendations. ${ }^{99}$ (The other dealt with road-traffic injuries.) It estimated that, out of a total child population in the United Kingdom of about 14 million, some 100,000 fell into this category. Of these, some 90,000 were suffering from congenital disability from ante-natal injury, genetic abnormality or birth injury or disease; between 1,000 and 2,000 had sustained post-natal injury; and about 8,000 suffered from disabling diseases acquired after birth. ${ }^{100}$ It considered that there was no reason to distinguish between these different groups and proposed that their needs should be met in the same way. ${ }^{101}$ The Pearson proposal was never implemented, but the issue of congenital disability has once again become the subject of official review in the United Kingdom. In his recent consultation paper, Making Amends, setting out proposals for reforming the approach to clinical negligence in the National Health Service (NHS), the Chief Medical Officer advocated the creation of a new right to no-fault compensation for children suffering cerebral palsy or other severe neurological impairment related to or resulting from their birth under NHS care. ${ }^{102}$ The proposal is, it must be admitted, rather limited. It only applies to birth-related impairments and excludes impairment resulting from genetic or chromosomal abnormality. And it is limited to births under NHS care, which lends credence to the view that the proposal's real motivation was to control the NHS's liability costs. But the Consultation Paper's rhetoric, at least, was that a no-fault approach was warranted by the special difficulties experienced by the families of children with cerebral palsy and other severe neurological impairments. As the paper observed, "the occurrence of cerebral palsy can be a tragedy for the child and family concerned."103 Models for such a reform were to be found in no-fault compensation schemes for birth-related neurological injuries in Virginia and Florida in the United States, introduced in 1988 and 1989 respectively. These too were substantially motivated by the concern to limit clinical negligence compensation costs, but they nevertheless testify to a recognition that severe congenital disability is a particularly deserving category of case. It is "deserving" not because of sentimentality concerning unfortunate children - though that is undoubtedly present - but because there is a principled case for the provision to them of no-fault compensation. Two factors points away from the reliance upon private initiative in such cases. One is the very extensive disruption caused to

99 Royal Commission on Civil Liability and Compensation for Personal Injury, Report (1978) Cmnd 7054, vol 1, para 281. The Commission's chairman was the Law Lord, Lord Pearson.

100 Royal Commission on Civil Liability and Compensation for Personal Injury, above n 99, vol 1, paras 151420.

101 Royal Commission on Civil Liability and Compensation for Personal Injury, above n 99, vol 1, para 1520.

102 Liam Donaldson, Making Amends: A Consultation Paper Setting out Proposals for Reforming the Approach to Clinical Negligence in the NHS (A Report by the Chief Medical Officer) (Department of Health, London, 2003) 120-121.

103 Donaldson, above n 102, para 2.40. 
family life by the birth of a severely-disabled child, or the later occasioning of such disability by disease (which might well be encompassed in any reform along the lines I am envisaging here). The adjustments required impact very considerably on family income, leisure time, the development of other children in the family, and general family well-being. The other consideration is the impossibility of adequate self-protection in advance. So far as I know, there is no insurance product which will protect against the financial consequences of severe disability to one's child. It is precisely in such situations - where the private insurance market does not offer a solution - that the State has most reason to assume a responsibility itself. Now, it may be argued that that responsibility is better fulfilled through the social security system than by the provision of no-fault compensation under ACC, and that could be so. But there may be a case for a more generous, and more flexible, response than can be expected from social security, one which removes the invidious distinction in treatment depending on whether the handicap has been caused by an accident or otherwise (for example, by illness or by genetic or chromosomal abnormality). One could argue, for example, for the payment of a lump sum, putting money immediately in the family's hands and providing a measure of solace. Where a parent is obliged to give up work to look after the child, maybe compensation should be related to their previous earnings, as if the parent had suffered a covered injury under ACC. Some weekly compensation could even be paid to the disabled person after they have attained the age of majority. And it may be that medical care and rehabilitation assistance are more suitable than that provided outside of ACC, especially where health service rationing is a factor. ${ }^{104}$ No matter how these issues are answered, however, they should at least be addressed, and my concern is that ACC's accident focus may have caused them to be overlooked.

\section{CONCLUSION}

In its Report on ACC, the Law Commission noted that there existed a tendency in some quarters to argue that, if the distinction between injury and illness could not be removed altogether, then nothing at all should be done to reduce its impact. That, the Commission objected, "invite[d] the response of the best being the enemy of the good."105 In my view, something of the tendency the Law Commission identified remains, and a preoccupation with "the best" - identified with "completion" of the project implicit in the principles of community responsibility and comprehensive entitlement - has resulted in a neglect of ways in which the "good" could be made better, and an excessive reliance upon the blunt distinction between (accidental) injury and (natural) illness. In this paper, I have argued that there is a need to identify new, mid-level principles that provide guidance as to how to draw the boundaries of ACC for as long as it remains a scheme of limited scope. The Woodhouse principles are not suited to that task as their logic points ineluctably to a compensation scheme covering incapacity of all sorts, without distinction between injury and

104 See Pauline Barnett and Anthea Penny "Dual Disability Systems in New Zealand: A Tandem or Two Separate Bicycles?" (2004) 22 Research Policy and Planning 11, 17.

105 New Zealand Law Commission, above n 27, paras 60-61. 
illness. I would not argue with those who maintain that as a long-term goal or aspiration. But in the short-to-medium term I believe it is necessary to adopt a principled approach to what is included in ACC and what is left outside, and, when extension is pursued, to do so by reference to a reasoned set of priorities. The failure to produce principled justifications for ACC's current boundaries is liable to lead to its portrayal as a failure that does not even live up to its own founding principles.

It is of course futile to look for a magic formula that will specify fully where no-fault's boundaries should be drawn. At best, we can expect some broad general guidance, perhaps ruling out certain solutions as contrary to principle (for example, the return to tort in respect of "nervous shock"), and highlighting options that have until now been overlooked because of the near exclusive focus on accidents (for example, the extension of cover to congenital disability). In this paper, I have argued that considering the nature of the dual public/private responsibility for incapacity may be of assistance. Where the question, "is it legitimate to leave this category of incapacity to the private sphere?", receives a negative answer, there is a case for extending ACC even if this means transgressing the boundary between injury and illness. 